Volume 4, Number 2, 2018

\title{
Determination of Hydro-Erosion Wear Coefficient for Sealing Elements of Pipeline Fittings
}

\author{
Zinoviy Stotsko*, Roman Sheremeta \\ Lviv Polytechnic National University, 12 S. Bandera St., Lviv, 79013, Ukraine
}

Received: June 02, 2018. Revised: October 23, 2018. Accepted: November 07, 2018.

(C) 2018 The Authors. Published by Lviv Polytechnic National University.

\begin{abstract}
A model of hydro-erosion wear of sealing elements was constructed taking into account a set of parameters that reflect the physical properties of the fluid and the material of the sealing elements, as well as the design parameters of the valves. To determine the dependence of the rate of erosion wear on a complex of parameters, we use the $\pi$ theorem of similarity and the method of dimension analysis. An expression is given that determines the change in the thickness of the erosive fracture of the sealing surfaces in time. The value of the maximum possible thickness of erosive fracture of valve elements is substantiated. The index of expenses relative growth, connected with wear of surfaces of sealing elements of the valve-seat system, is presented. The algorithm for determining the rate of wear of elements of the valve-seat system is proposed on the basis of calculation of the coefficient of hydro-erosion wear of the specific pipeline armature elements, which makes it possible to determine the total amount of wear during a certain operating time.
\end{abstract}

Keywords: pipeline fittings; valve-seat; erosion; simulation.

\section{Introduction}

Modern technological equipment often includes pneumatic hydraulic systems of high energy parameters [1]. When operating such systems, there is erosion wear of the sealing surfaces of valve-seat elements. This leads to changes in the hydraulic characteristics of the regulating (throttle), shut-off valves and ultimately to the failure of the whole system [2].

To determine the factors leading to the erosive destruction the elements of hydraulic fittings, it is necessary to conduct a study the process of fluid flow through the gap clearance of the valve shutter.

\section{Presentation of the main material}

When constructing a model of hydro-erosion wear of sealing elements, it is necessary to take into account a set of parameters that reflect the physical properties of the fluid and the material of the sealing elements, the operating modes of the hydraulic system, and the design parameters of the valves $[3,7]$. For the bypass valve-seat system, the scheme of which is presented in Fig. 1, these parameters can be as follows:

$\rho$ - working fluid density, $\mathrm{kg} / \mathrm{m}^{3}\left[L^{-3} M\right]$;

$\mu$ - dynamic viscosity of the liquid, $\mathrm{Pa} \cdot \mathrm{s}\left[L^{-1} M T^{-1}\right]$;

$Q$ - flow of the working fluid, $\mathrm{m}^{3} / \mathrm{s}\left[L^{3} T^{-1}\right]$;

$H$ - hardness of the material of the valve seat, $\mathrm{Pa}\left[L^{-1} M T^{-2}\right]$;

\footnotetext{
*Corresponding author. Email address: stotsko@1p.edu.ua
}

This paper should be cited as: Z. Stotsko, R. Sheremeta. Determination of hydro-erosion wear coefficient for sealing elements of pipeline fittings. Energy Eng. Control Syst., 2018, Vol. 4, No. 2, pp. 59 - 64. https://doi.org/10.23939/jeecs2018.02.059 
$V$ - velocity of the fluid relative to the sealing surface, $\mathrm{m} / \mathrm{s}\left[L T^{-1}\right]$;

$t$-operating time of sealing, $\mathrm{s}[T]$.

The wear of the sealing surface can be estimated by the volume of the removed (damaged) surface of the seat and valve during the operation of the valve element. Let's denote with $Z$ the velocity of the volume erosion wear of sealing surfaces, $\mathrm{m}^{3} / \mathrm{s}\left[L^{3} T^{-1}\right]$. This parameter depends on the construction of the valve pair, as well as on the factor of physicochemical interaction of the working fluid with the material of the valve sealing elements.

Taking into account that the viscosity and density of the working fluid, the flow rate and the velocity of the fluid are interrelated values, we can represent the value of wear per time unit in the form of power dependence

$$
Z=k \mu^{a} H^{b} V^{c}
$$

where $\mathrm{k}, \mathrm{a}, \mathrm{b}, \mathrm{c}$ are unknown numerical coefficients.
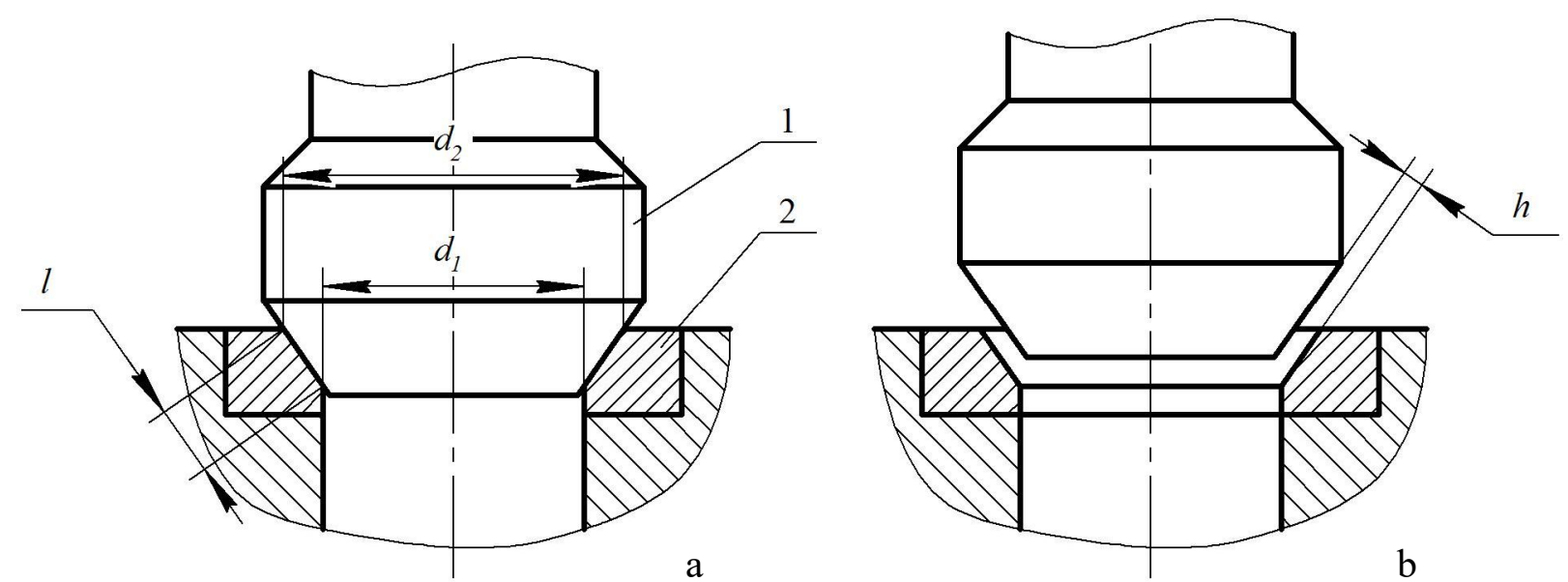

Fig. 1. Diagram of the valve seal in the closed state (a) and during the passage in working environment (b): 1 - valve; 2 - seat.

To determine this dependence, we apply the $\pi$-similarity theorem and the dimensional analysis method. Equation (1) is a complete equation of the physical process of wear of the seat surface, and $k$ is the coefficient of proportionality. Substituting dimension values, we obtain

$$
L^{3} T^{-1}=\left(L^{-1} M T^{-1}\right)^{a}\left(L^{-1} M T^{-2}\right)^{b}\left(L T^{-1}\right)^{c}(T)^{d} .
$$

From here we can find:

$$
a=2 ; b=-2 ; c=3 \text {. }
$$

Consequently, the wear rate of the sealing elements of the valve pair is determined by the formula

$$
Z=k \frac{\mu^{2} V^{3}}{H^{2}}
$$

where $k$ is dimensionless coefficient of wear, which is determined experimentally; $V$ is the velocity of the fluid, which is determined taking into account the flow of liquid $Q$ through the section of the annular gap $S$ between the seat and the valve

$$
V=\frac{Q}{S},
$$


where $Q$ is the flow rate of working fluid; $S$ is the cross-sectional area of the gap between the seat and the valve, $S=\pi D h$. Here $D$ is diameter of the contact cylindrical surface; $h$ is the value of the gap between the valve and the seat (Fig. 1, b).

Thus, the rate of erosion wear of sealing elements can be determined by the formula

$$
Z=k \frac{\mu^{2} Q^{3}}{(\pi D h)^{3} H^{2}}
$$

Then the total volume of wear $\Omega$ during the time $t$ of the sealing operation:

$$
\Omega=Z \cdot t=k \frac{\mu^{2} Q^{3}}{(\pi D h)^{3} H^{2}} \cdot t
$$

If we consider the gap between the valve and the seat in the form of a ring gap, then the amount of wear, provided the same hardness of the valve and the seat materials, can be represented as

$$
\Omega=2 \cdot \delta \cdot l \cdot \pi D
$$

where $\delta$ is the depth of erosive fracture of the surface of the sealing elements of the valve pair; $l$ is the width of the valve clearance in the direction of the flow of the working environment.

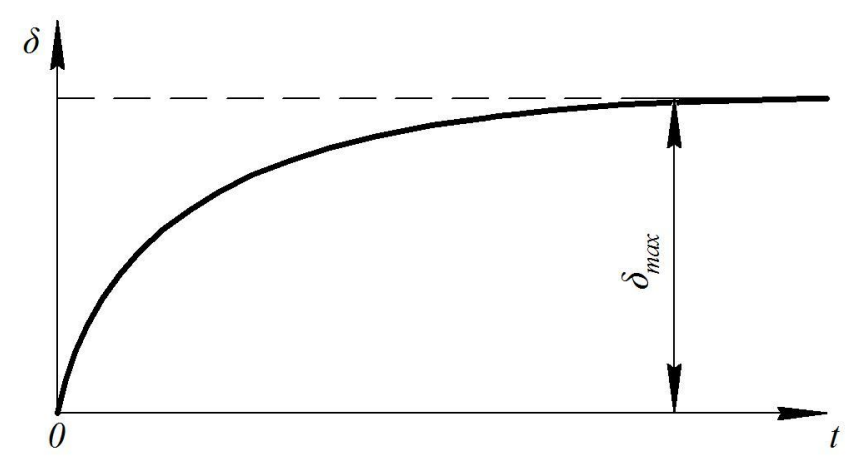

Fig.2. Dependence of change in the thickness of the erosion layer on the time of the liquid flow.

The availability of experimental data allows mathematically describing the process of erosion of the crack due to the movement of the working fluid. When the liquid flows through the crack, the thickness of the erosive layer $\delta$ on the surface of the sealing elements increases with time, tends to some limit value (Fig. 2). This is explained by the fact that as the gap $h$ increases, the velocity of the fluid in the crack decreases, and this, according to expression (2), decreases the rate of erosion wear in accordance with the cubic dependence. Change in the thickness of erosive fracture in time of sealing surfaces can be described by dependence [4]

$$
\delta=\delta_{\max }\left(1-e^{-\alpha t}\right)
$$

where $\delta_{\max }$ is the maximum possible thickness of erosive fracture; $t$ is time from the beginning of the environment; $\alpha$ is the coefficient of proportionality, which depends on the type of fluid and the material of the sealing elements; $e$ is the basis of the natural logarithm.

From the formula it is clear that for $t \rightarrow \infty$, the thickness of the layer destroyed by erosion $\delta \rightarrow \delta_{\max }$ and for $t \rightarrow 0$ $\delta \rightarrow 0$. In this case, the coefficient $k$ in expression (4) is a function of time and using the expression (5) is defined as

$$
k=\frac{2(\pi D)^{4} H^{2} l}{\mu^{2} Q^{3} t} \cdot \delta_{\max }\left(1-e^{-\alpha t}\right) \cdot\left[h_{0}+2 \delta_{\max }\left(1-e^{-\alpha t}\right)\right]^{\beta} .
$$


The flow rate $Q_{0}$ through the valve pair at the initial moment (at $t=0$ ) for the viscous flow regime is described by the Poiseuille equation $[5,6]$ :

$$
Q_{0}=\frac{\pi D h_{0}^{3} \Delta p}{8 \mu \cdot l}
$$

where $h_{0}$ is the value of the initial gap; $l$ is the width of the valve clearance in the direction of flow of the medium; $\Delta p$ is the pressure difference between the inlet and outlet of the valve seal.

Due to erosion wear, the flow rate $Q$ through the valve seal will increase with time [8], because the gap will be variable, $h=h_{0}+2 \delta=h_{0}+2 \delta_{\max }\left(1-e^{-\alpha t}\right)$, therefore

$$
Q=\frac{\pi D h_{0}^{3} \Delta p}{8 \mu \cdot l} \cdot\left[h_{0}+2 \delta_{\max }\left(1-e^{-\alpha t}\right)\right]
$$

When maintaining the value of the pressure difference $\Delta p$ constant and neglecting the change in the length of the gap $\pi D$ caused by the destruction, the expense $Q$ taking into account (8) is expressed in the form of dependence

$$
Q=\frac{\pi D h_{0}^{3} \Delta p}{8 \mu l}\left[1+\frac{2 \delta_{\max }}{h_{0}}\left(1-e^{-\alpha t}\right)\right]^{3}=Q_{0}\left[1+\frac{2 \delta_{\max }}{h_{0}}\left(1-e^{-\alpha t}\right)\right]^{3} .
$$

The relative growth of expenses associated with the wear of the surfaces of the sealing elements of the valve-seat system, will be presented as an indicator $v=\frac{\mathrm{Q}-\mathrm{Q}_{0}}{\mathrm{Q}_{0}}$. Then, taking into account (10), the relative growth of expenses is determined by the dependence

$$
v=\left[1+\frac{2 \delta_{\max }}{h_{0}}\left(1-e^{-\alpha t}\right)\right]^{3}-1 .
$$

For $t=0 v=0$, for $t \rightarrow \infty$ the value $v \rightarrow v_{\max }$, it stabilizes and from expression (11) we obtain

$$
v_{\max }=\left(1+\frac{2 \delta_{\max }}{h_{0}}\right)^{3}-1
$$

In experimental studies, according to the criterion for stabilizing the flow, it is possible to choose the value $v$ for which $\frac{\mathrm{d} v}{\mathrm{dt}} \leq\left. 0.1 \% \cdot \frac{\mathrm{d} v}{\mathrm{dt}}\right|_{t=0}$. The equation (12) allows determining the maximum possible thickness of erosion wear of the material of the valve vapor elements:

$$
\delta_{\max }=\frac{h_{0}}{2}\left(\sqrt[3]{v_{\max }+1}-1\right)
$$

To determine the value of the coefficient of proportionality $\alpha$ we find the derivative of expression (11) in time $t$ :

$$
\frac{d \nu}{d t}=3 \alpha e^{-\alpha t} \frac{2 \delta_{\max }}{h_{0}}\left[1+\frac{2 \delta_{\max }}{h_{0}}\left(1-e^{-\alpha t}\right)\right]^{2}
$$

for $t=0, e^{-\alpha t}=1$, then 


$$
\left.\frac{\mathrm{d} v}{\mathrm{dt}}\right|_{t=0}=3 \alpha \frac{2 \delta_{\max }}{h_{0}} .
$$

Thus

$$
\alpha=\frac{1}{3} \cdot \frac{\left.\frac{d v}{d t}\right|_{t=0}}{\sqrt[3]{v_{\max }+1}-1} .
$$

Dependence of the relative growth of expenses through the valve clearance on the time of the liquid flow is constructed in the course of experimental research (Fig. 3).

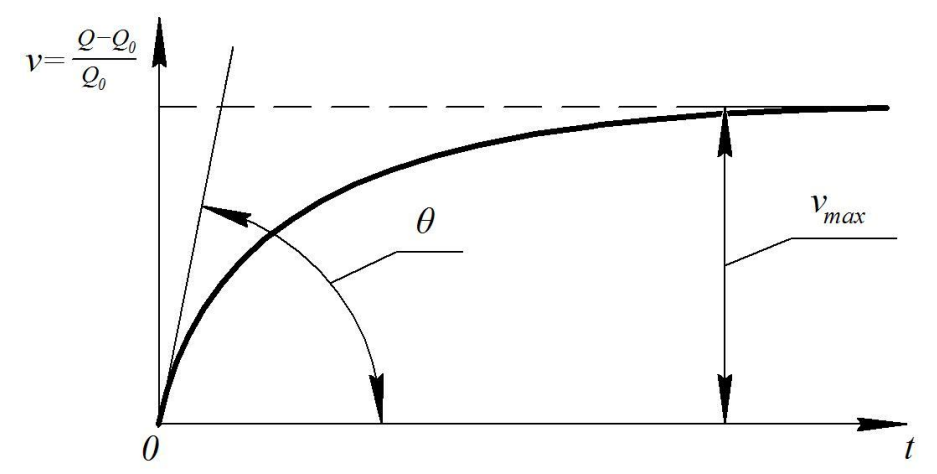

Fig. 3. Dependence of the relative change of expenses in the process of erosion wear on the time of the liquid flow:

$\theta$ is the angle of inclination of the tangent to the curve at the point $t=0$.

Based on this graph (Fig. 3) we can determine the value of $v_{\max }$, as well as $\left.\frac{\mathrm{d} v}{\mathrm{dt}}\right|_{t=0}$ by graphically differentiating the curve at the corresponding point

$$
\left.\frac{\mathrm{d} v}{\mathrm{dt}}\right|_{t=0}=\tan \theta
$$

Taking into account (6), (13), (14), we find the value of the functional $k$ from the equation (7) for each particular system working fluid-valve seal. Thus we can determine the wear rate of the sealing elements, and therefore the total amount of wear (4) over a specified period of sealing operation using formula (3).

\section{Conclusion}

The developed mathematical model allows determining the rate of hydro-erosive deterioration of sealing surfaces of pipeline armature elements depending on the parameters of the flow of liquid and the design parameters of the bypass system.

The algorithm for determining the rate of wear of elements of the valve-seat system is proposed on the basis of calculation of the coefficient of wear of the concrete pipeline armature elements, which makes it possible to determine the total amount of wear during a certain operating time.

\section{References}

[1] Chegodaev D.E., Mulyukin O.P. Elements of valve assemblies of aircraft assemblies and their reliability. Publish. MAI, Moscow, 1994, 208 p. (in Russian)

[2] Sheremeta R.M., Bilous B.D. Analysis of causes of leakage through sealing elements. Proc. of Lviv Polytechnic State University: Problems of Energy Saving, No. 2, 1999, pp. 250-254. (in Ukrainian)

[3] Sheremeta R.M., Bilous B.D. Principles of rational design of shut-off and regulating pipeline valves. Proc. of 4th Intern. Scient. and Pract. Conf. "Problems of energy saving”. Lviv: Publishing House of Lviv Polytechnic National University, 8-12 Oct., 2003, 152-153 p. (in Ukrainian) 
[4] P.M. Ogar, D.B. Gorohov, R.M. Sheremeta. Obliteration of joints of sealing junctions. Journal: Systems. Methods. Technologies. 2015, No.2. Federal State Budget Educational Institution of Higher Professional Education "Bratsk National University", pp. 16-23 (in Russian)

[5] http://files.lib.sfu-kras.ru/ebibl/umkd/u course/Lekc/Part2/Glava6/6.10.htm

[6] Nikitin G.A. Slot and labyrinth seals of hydraulic units. Mechanical Engineering, Moscow, 1982, 135 p. (in Russian)

[7] Sheremeta R.M., Dolotov A.M., Ogar P.M., Pushkarsky Ya. A. Rational construction of gate valves of pipeline valves. Proceedings of zonal scient. and techn. conf. "Ways to improve the design of pipeline fittings", Penza, 1988, pp. 75-76. (in Russian)

[8] Sheremeta R.M. To the question of optimal profiling of metal-polymeric sealing elements. Proc. of Lviv Polytechnic State University: Optimization of production processes and technical control in mechanical engineering and instrument making, No. 359, 1999, pp. 67-70. (in Ukrainian)

\title{
Визначення коефіціснта гідроерозійного зносу ущільнювальних елементів трубопровідної арматури
}

\author{
Зіновій Стоцько, Роман Шеремета \\ Національний університет «Львівська політехніка», вул. С. Бандери, 12, м. Львів, 79013, Украӥна
}

\section{Анотація}

Побудована модель гідроерозійного зносу ущільнюючих елементів з врахуванням комплексу параметрів, що відображають фізичні властивості рідини і матеріалу ущільнювальних елементів, а також конструктивні параметри клапанів. Для визначення залежності швидкості ерозійного зносу від комплексу параметрів застосовано $\pi$-теорему подібності і метод аналізу розмірностей. Наведено вираз, що визначає зміну товщини ерозійного руйнування ущільнювальних поверхонь в часі. Обгрунтовано значення максимально можливої товщини ерозійного руйнування елементів клапанної пари. Представлено показник відносного зростання витрат, пов'язаного зі зношуванням поверхонь ущільнювальних елементів системи клапан-сідло. Запропоновано алгоритм визначення швидкості зношування елементів системи клапан-сідло на основі розрахунку значення коефіцієнту гідроерозійного зносу елементів конкретної трубопровідної арматури, що дає можливість визначити сумарний об’єм зношування протягом визначеного часу роботи.

Ключові слова: трубопровідна арматура; клапан-сідло; ерозія; моделювання. 